УДК 595.762.12:504.064

\author{
В. В. Болгарін
}

Нікопольський інститут Запорізького наиіонального університету

\title{
ПРОСТОРОВИЙ РОЗПОДІЛ ПОПУЛЯЦЙ ТУРУНІВ-МІКСОФІТОФАГІВ В УМОВАХ ПРОМИСЛОВОГО МІСТА (НА ПРИКЛАДІ М. НІКОПОЛЬ)
}

\begin{abstract}
Вивчено вплив абіотичних факторів на види Amara, Ophonus, Harpalus у міському середовищі. Проаналізовано особливості розподілу турунів за районами м. Нікополь. 3'ясовано дію проїзної частини на життсдіяльність імаго жужелиць родів Amara, Ophonus, Harpalus у м. Нікополь. Встановлено перевагу природних факторів над антропогенними для існування мезофауни у м. Нікополь.
\end{abstract}

\section{В. В. Болгарин}

Никопольский институт Запорожского национального университета

\section{ПРОСТРАНСТВЕННОЕ РАСПРЕДЕЛЕНИЕ ПОПУЛЯЦИЙ ЖУЖЕЛИЦ-МИКСОФИТОФАГОВ В УСЛОВИЯХ ПРОМЫШЛЕННОГО ГОРОДА (НА ПРИМЕРЕ Г. НИКОПОЛЬ)}

Изучено воздействие абиотических факторов на виды Amara, Ophonus, Harpalus в городской среде. Проанализированы особенности распределения жужелиц по районам г. Никополь. Выявлено влияние проезжей части на жизнедеятельность имаго жужелиц родов Amara, Ophonus, Harpalus в г. Никополь. Установлено преимущество природных факторов над антропогенными для существования мезофауны в г. Никополь.

$$
\text { V. V. Bolgarin }
$$

Nikopol Institute of Zaporizhzhya National University

\section{SPATIAL DISTRIBUTION OF THE GROUND BEATLES POPULATIONS IN INDUSTRIAL CITIES (ON THE EXAMPLE OF NIKOPOL)}

The influence of abiotic factors on species of Amara, Ophonus, Harpalus in the urban environment has been studied. The features of the ground beetles distribution in the districts of Nikopol have been analysed. The influence of roadway on the vital fuctions of ground beetles has been cleared up. Quantitative data of Amara, Ophonus, Harpalus numbers in the town of Nikopol have been discussed. The advantage of natural factors over anthropogenic ones for the existence of soil mesofauna in industrial town has been established.

\section{Вступ}

Прогресуюча урбанізація - об’єктивне явище сучасної цивілізації, яке призводить до локальної інтенсифікації антропогенних факторів, необоротних змін природних біогеоценозів [5; 8]. Район досліджень - м. Нікополь - розташований на правому березі р. Дніпро в межах південної частини Дніпропетровської області. Нікополь належить до найбільш індустріально розвинених міст України [15]. У структурі промисловості переважають екологічно небезпечні виробництва: 
1) металургійної галузі (ВАТ «Нікопольський завод феросплавів», ЗАТ «Нікопольський завод нержавіючих труб», НВО «Трубосталь», ВАТ «Нікопольський завод трубопровідної арматури»);

2) галузі машинобудування (НВО «Кранобудівний завод»);

3) комунальні підприємства (Нікопольське КП «Західне»).

Якість навколишнього середовища Нікополя визначається забрудненням повітряного та водного басейнів, міських грунтів, переробкою й утилізацією відходів, деградацією зелених насаджень тощо [1; 15].

Проїзна частина надає різні види впливів на тваринний світ: туруни гинуть під час руху транспорту та під дією підвищеної температури на асфальті (не маючи змоги сховатися у грунт). Дорога ізолює місця існування Carabidae одне від іншого. Транспортні викиди та інші полютанти впливають на фауну узбіч, так що тут можуть виникати нові асоціації - так звані антропогенні зональні зооценози [2; 20-22].

Абіотичні фактори у межах проїзної частини суттєво відрізняються від інших територій (сильне прогрівання, посилений поверхневий стік, слабке випаровування) i створюють особливі мікрокліматичні градієнти освітленості, температури поверхні грунту та випаровування $[5 ; 6 ; 14]$. Вочевидь, існує такий ланцюг дій: зміна абіотичних факторів під впливом проїзної частини $>$ зміна рослинних угруповань $>$ формування зональних зооценозів під впливом специфічних механічних впливів і шкідливих викидів.

Жужелиці (Coleoptera, Carabidae) - надійні індикатори екологічного режиму, важливий компонент фауни більшості наземних екосистем. До нових умов середовища туруни переходять із тими екологічними характеристиками, які вони придбали у ході адаптивної еволюції в інших природних екосистемах $[2 ; 3 ; 10]$.

Мета цієї роботи - оцінити чисельність і особливості просторового розподілу турунів-міксофітофагів у місті Нікополь.

\section{Матеріал і методи досліджень}

Нікополь розташований у степовій зоні України з континентальним кліматом $[1 ; 11]$. Це, безумовно, впливає на вологість грунту, видове різноманіття трав'яних угруповань, розподіл сонячної радіації та інші природні фактори [15]. При проведенні досліджень у м. Нікополь розглядали значимість різних факторів для домінантної групи підстилкової мезофауни - турунів. Із природних факторів - це проективне покриття рослинності, видове багатство травостою, вологість грунту, тривалість існування біоценозу, з антропогенних - частота косіння травостою, ступінь рекреації, рівень забруднення атмосферного повітря та грунту [6;20;21]. Жуків збирали в межах Нікополя в 2009 р. у різних районах міста (рис.).

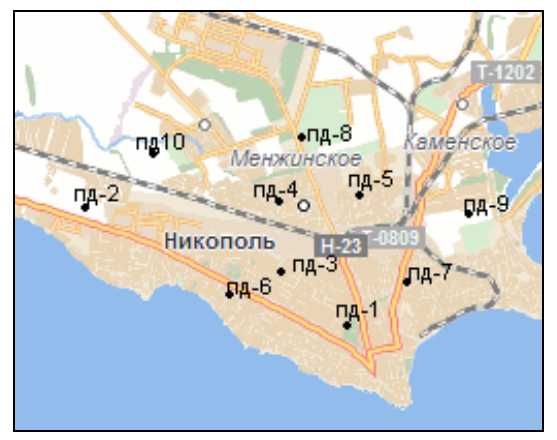

Рис. Схема розташування пробних ділянок (ПД-1-10) на території м. Нікополь Дніпропетровської області 
Обстежено такі пробні ділянки (ПД): ПД 1 розташована у парковій зоні центру міста, ПД 2 - парк на околиці, ПД 3, 4 та 5 - спортивні майданчики, ПД 6, 7 та 8 - узбіччя доріг, ПД 9 і 10 - рудеральні угруповання на околиці міста. Жуків збирали за стандартною методикою пастками Барбера (фіксатор - $20 \%$ розчин $\mathrm{NaCl}$ ) на початку літа та восени [18].

\section{Результати та їх обговорення}

Видове різноманіття турунів міських парків Нікополя підвищується зі збільшенням проективного покриття рослинності та кількості видів у травостої. Високий рівень рекреації на різних площах знижує чисельність видів карабідофауни [8; 23]. Окрему позицію займають місця проживання турунів поблизу дороги. Нікополь, як і будь-яке промислове місто, отримує різноманітну масу викидів. Узбіччя доріг зазнає впливу комплексу шкідливих факторів, наприклад солі (яку використовують для танення снігу взимку), пилу, важких металів (марганцю, нікелю, свинцю тощо), фотосмогу [2; 11; 16$]$.

При аналізі чисельності турунів виявлене зменшення ступеня домінування багатьох видів від околиць до центру міста. Причинами можна вважати перш за все збіднення кормового раціону, зниження різноманіття місць існування, а у деяких груп підвищення смертності під впливом антропогенних чинників. Відзначається збіднення фауни через наявність зелених масивів на околицях до зони суцільної забудови центру міста. У місті зустрічалась більша частина видів, притаманна Дніпропетровській області [3]. Найчисельнішими виявились Amara chaudoiri Putzejs, 1858, A. similata (Gyllenhal, 1810), Zabrus tenebrioides (Goeze, 1777), Harpalus griseus (Panzer, 1797), H. rufipes (De Geer, 1774). Кожен рід має свої трофічні зв'язки, пристосовані під живлення у місті. Слід відзначити, що приблизно половину площі м. Нікополь займають приватні домоволодіння, на території яких розташовані городи та сади, де й існує велика частина турунів.

Рід Amara широко використовує трофічні ресурси даного регіону. A. aеnea (De Geer, 1774) та A. municipalis (Duftschmid, 1812) зустрічаються більше на околицях, де поширені дикорослі трави, що входять до їх раціону (злаки, осокові, гвоздичні, хрестоцвіті, айстрові). Часто трапляються A. ingenua (Duftschmid, 1812), A. ovata (Fabricius, 1792), A. fulva (O. Muller, 1776), A. similata, A. eurynota (Panzer, 1797), які споживають городні культури (редис, салат, молоді пагони картоплі, молоду капустяну розсаду, горох, квасолю, суниці тощо), зернові (пшеницю, жито, кукурудзу), падалиці у фруктових садах $[4 ; 7 ; 13]$.

Zabrus tenebrioides i Z. (Pelor) spinipes steveni Fischer von Waldheim, 1817 шкідники, поширені по всій степовій зоні. На околицях Нікополя вони ушкоджують зернові (пшеницю, жито, кукурудзу, овес), технічні (соняшник, буряк), городні (салат), кормові культури та деякі види дикорослих злаків [4; $13 ; 17]$.

Ophonus puncticollis (Paykull, 1798) і O. rupicola (Sturm, 1818) в умовах міста поїдають генеративні органи зернових (ячмінь, гречка), технічні (гірчиця), овочеві (салат) і лікарські (звіробій) культури [4].

Harpalus rufipes i H. zabroides Dejean, 1829 живляться зерновими (пшениця, жито, просо, овес, кукурудза, ячмінь, гречка), шкодять бурякам, деяким городнім культурам, виїдають плоди суниці та падалицю в садах. H. picipennis (Duftschmid, 1812) спорадично ушкоджує насіння зернових (пшениця, просо), лікарських (подорожник великий, спаржа лікарська), городніх культур (морква), ягоди суниці. У місті часто зустрічається H. affinis (Schrank, 1781), при цьому він шкодить зернобобовим (горох), технічним (буряк, гірчиця, льон), лікарським (подорожник великий) і городнім (салат, 
огірки) культурам. 3 інших рослин пошкоджує суницю, дикорослі злаки. H. fuscipalpis (Sturm, 1818) трапляється рідко внаслідок того, що з міського раціону може вживати тільки падалиці в садах $[4 ; 7 ; 13]$.

Наявність у м. Нікополь великої кількості металургійних, хімічних, комунальних підприємств, близькість Каховського водосховища та інші фактори підвищують рівень забруднення атмосферного повітря, води та грунту, впливаючи на біологічне різноманіття та, зокрема, на фауну турунів [1]. У порядку зменшення впливу фактори можна розташувати таким чином: 1) вологість грунту; 2) частота косіння травостою; 3) тривалість існування біоценозу; 4) проективне покриття; 5) ступінь рекреації; 6) рівень забруднення атмосферного повітря; 7) рівень забруднення грунту.

\section{Висновки}

Кількість видів турунів зростає від центру до околиць міста. Близькість проїзної частини зменшує їх чисельність. Вологість грунтового покриву, тривалість існування біоценозу, частота косіння травостою - найвпливовіші фактори міського середовища для життєдіяльності турунів в умовах м. Нікополь.

Найбільшої чисельності у межах міста досягають Amara aenea, A. ingenua, A. ovata, A. similata, A. eurynota, Zabrus tenebrioides, Z. spinnipes, Harpalus rufipes, H. griseus, H. picipennis. Це свідчить про велику екологічну пластичність цих видів, їх здатність переносити несприятливі умови штучних урбоценозів.

Такі розповсюджені у степу види як Harpalus affinis, Ophonus puncticollis трапляються у міському середовищі дуже рідко. Цей факт свідчить про слабку їх можливість пристосовуватись до змін, які відбуваються у промисловому місті.

\section{Бібліографічні посилання}

1. Болгарін В. В. Антропогенний вплив на мезофауну Нікопольського району Дніпропетровської області // Биоразнообразие и роль животных в экосистемах. Матер. V Междунар. научн. конф. - Д. : Лира, 2009. - С. 141-142.

2. Бригадиренко В. В. Вплив автомагістралі на окремі компоненти герпетобію штучних лісонасаджень Дніпропетровської області / В. В. Бригадиренко, О. С. Черниш // Вісник Дніпропетр. ун-ту. Біологія. Екологія. - 2003. - Вип. 11, т. 1. - С. 76-84.

3. Бригадиренко В. В. Фауна жужелиц (Coleoptera, Carabidae) Днепропетровской области // Проблемы экологии и охраны природы техногенного региона. - Вып. 3. - Донецк : ДонНУ, 2003. - C. 77-86.

4. Вредители сельськохозяйственных культур и лесных насаждений / Под ред. В. П. Васильева. К. : Урожай, 1973. - Т. 2. - 362 с.

5. Еремеева Н. И. Население жужелиц городских газонов / Н. И. Еремеева, Н. А. Коровина, Н. И. Савосин // Экология фундаментальная и прикладная. Проблемы урбанизации. Матер. Междунар. научн.-практ. конф. - Екатеринбург : Изд-во Уральского ун-та, 2005. - С. 123-125.

6. Коровина Н. А. Население жужелиц (Coleoptera, Carabidae) в промышленной зоне г. Кемерово. Видовой состав и структура доминирования // Сб. трудов молодых ученых КемГУ, посвященный 30-летию Кемеровского гос. ун-та. - Кемерово : Полиграф, 2004. - Вып. 4. - С. 254-255.

7. Крыжановский О. Л. Жуки подотряда Adephaga: ceм. Rhysopidae, Trachypachydae; сем. Carabidae (вводная часть, обзор фауны СССР). - Л. : Наука, 1983. - 341 с.

8. Клауснитцер Б. Экология городской фауны. - М. : Мир, 1990. - 246 с.

9. Кульбачко Ю. Л. Особенности накопления тяжелых металлов жужелицами в биогеоценозах, подверженных химическому загрязнению // Вісник Дніпропетр. ун-ту. Біологія. Екологія. 1998. - Вип. 4. - С. 63-68. 
10. Лапин Е. И. Индикация техногенных загрязнений по фаунистическим комплексам жесткокрылых / Е. И. Лапин, С. В. Израилевич // Сб. работ Х съезда Всесоюзн. энтомол. о-ва. - Л. : ЛГУ, 1989. - С. 75-77.

11. Національна доповідь про стан навколишнього природного середовища в Україні у 2003 р. K., 2004. -227 c.

12. Пучков А. В. Обзор карабидофауны (Coleoptera, Carabidae) Украины и перспективы ее изучения // Вестник зоологии. - 1998. - Отд. вып. № 9. - С. 151-154.

13. Сумароков А. М. Материалы к видовому составу фауны жесткокрылых (Insecta: Coleoptera) Днепропетровской области // Пробл. экологии и охраны природы техногенного региона. Донецк : ДонНУ, 2004. - Вып. 4. - С. 131-142.

14. Тимофеева Г. А. Популяционные аспекты экологии жужелиц в условиях большого города (на примере г. Казани) / Г. А. Тимофеева, Р. А. Суходольская // Современные проблемы эволюции. ХХІІ Любишевские чтения. - Ульяновск, 2008. - Т. 2. - С. 249-252.

15. Пасічний Г. В. Фізична та економічна географія Дніпропетровської області. - Д. : ДдУ, 1992. $-77 \mathrm{c}$.

16. Цвєткова Н. М. Вміст і поширення купруму у природних і антропогенних грунтах степового Придніпров'я // Н. М. Цвєткова, А. О. Дубіна, С. М. Замліла // Вісник Дніпропетр. ун-ту. Біологія. Екологія. - 2009. - Вип. 17. - С. 106-114.

17. Шарова И. Х. Жизненные формы жужелиц (Coleoptera, Carabidae). - М. : Наука, 1981. - 360 с.

18. Barber H. S. Traps for cave-inhabiting // J. Elish. Mitcell. Sci. Sos. - 1931. - Vol. 46, N 3. - P. 259-266.

19. Loreau M. Occupation of space by the carabid beetle Abax ater / M. Loreau, C.-L. Nolf // Acta Oecologica. - 1993. - Vol. 14. - P. 247-258.

20. Magura T. Time-consistent rearrangement of carabid beetle assemblages by an urbanisation gradient in Hungary / T. Magura, G. L. Lövei, B. Tóthmérész // Acta Oecologica. - 2008. - Vol. 34. - P. 233-243.

21. Magura T. A species-level comparison of occurrence patterns in carabids along an urbanisation gradient / T. Magura, G. L. Lövei, B. Tóthmérész // Landscape and Urban Planning. - 2008. Vol. 86. - P. 134-140.

22. Magura T. Body size inequality of carabids along an urbanisation gradient / T. Magura, G. L. Lövei, B. Tóthmérész // Basic and Applied Ecology. - 2006. - Vol. 7. - P. 472-482.

23. Thiele H.-U. Carabid beetles in their environments. A study on habitat selection by adaptations in physiology and behaviour. - Berlin : Springer, 1977. - 370 p.

Надійшла до редколегії 09.04.2010 